\title{
Effects of Short Dry Periods on Performance and Metabolic Status in Holstein Dairy Cows
}

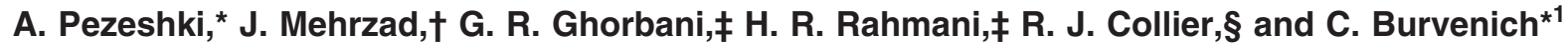 \\ ${ }^{*}$ Ghent University, Faculty of Veterinary Medicine, Department of Physiology and Biometrics, Salisburylaan 133, B-9820, Merelbeke, Belgium \\ †Ferdowsi University of Mashhad, Faculty of Veterinary Medicine, Department of Pathobiology, Section Immunology, 91775-1793, \\ Mashhad, Iran \\ ‡Department of Animal Sciences, Isfahan University of Technology, Isfahan 84156, Iran \\ $\S D$ Department of Animal Sciences, University of Arizona, Tucson 85721
}

\begin{abstract}
To evaluate effects of different dry period lengths on milk yield, milk composition, and energy balance of dairy cows, 122 multiparous and primiparous Holstein dairy cows were used in a completely randomized experimental design with 56-, 42-, and 35-d dry period lengths. Actual dry period lengths for respective treatments (TRT) were $56 \pm 5.1 \mathrm{~d}, 42 \pm 2.1 \mathrm{~d}$, and $35 \pm 2.7$ $\mathrm{d}$. Overall, cows in the 42- and 56-d TRT gained more body condition than those in 35-d TRT during the dry period; however, postpartum body condition score did not change substantially among the TRT. Although from 3 to 210 DIM, differences were not detected in the milk yield of multiparous cows between the 35- and 56$\mathrm{d}$ TRT, primiparous cows in the 35-d TRT produced less milk than those in 56-d TRT. In primiparous cows, the milk production at wk 9,10 , and 11 of lactation was lower in the 35-d compared with the 56-d TRT. Primiparous cows in the 35-d compared with the 56-d TRT produced less milk protein. In the 35 -d TRT, serum triglyceride concentration was greater in primiparous cows than in multiparous cows during the peripartum period. Among primiparous cows, those in the 56-d TRT had greater concentrations of nonesterified fatty acids than those in the 35-d TRT during the peripartum period. No significant differences were observed in concentrations of serum glucose, insulin, and insulin-like growth factor-I during early lactation among TRT. There was also no difference among TRT for incidence of metabolic disorders. Thus, this study indicates that shortening the dry period to $35 \mathrm{~d}$ may be beneficial in multiparous and overconditioned cows, but not in primiparous cows.
\end{abstract}

Key words: dry period, metabolic status, performance

Received May 11, 2007.

Accepted August 17, 2007.

${ }^{1}$ Corresponding author: Christian.Burvenich@UGent.be

\section{INTRODUCTION}

A dry period is necessary for involution of the mammary gland and maximizing milk yield in the subsequent lactation in cattle (Coppock et al., 1974; Hurley, 1989; Cameron et al., 1998; Rastani et al., 2005). A 51to 60-d dry period has been a management constant for most dairy farms since World War II (Bachman and Schairer, 2003). It has long been known that shortening the dry period (to $<40 \mathrm{~d}$ ) depresses milk yield (Coppock et al., 1974; Swanson, 1965; Wheelock et al., 1965). Also, lengthening the dry period (to $>60 \mathrm{~d}$ ) may increase costs and decrease the productive longevity of dairy cows (Hurley, 1989). Additional milk is produced in the previous lactation when the dry period is reduced, which is beneficial if there is no yield depression in the subsequent lactation. A shorter dry period reduces the frequency of diet change, thus reducing stress. Also, reduced dietary changes in the dry period may improve the survival of desirable population of rumen microbial flora. Complete omission of the dry period results in considerable depression in milk synthesis and secretion during the next lactation. Most studies with the purpose of determining optimal dry period length have been carried out with observational data (Smith and Legates, 1962; Wilton et al., 1967; Smith and Becker, 1995). Recently, several designed studies have evaluated dry period lengths. These studies reported a range in milk yield changes from a 10\% decrease to a $1 \%$ increase when the dry period length was shortened from 50-57 $\mathrm{d}$ to $30-34 \mathrm{~d}$. However, depression in milk yield in the subsequent lactation was somewhat compensated by extension of the lactation period in the previous lactation (Bachman and Schairer, 2003; Grummer and Rastani, 2004; Kuhn and Hutchison, 2005).

Involution of the mammary gland during the dry period is associated with mammary cell apoptosis and proliferation. Mammary epithelial cell turnover during the dry period is very important for replacement of senescent cells. Mammary involution in ruminants is not as extensive as that in rodents (Pandey et al., 1978; 
Table 1. Summary of the number of cows in each group, cows removed from each group, and reasons for removal

\begin{tabular}{|c|c|c|c|}
\hline $\begin{array}{l}\text { Length } \\
\text { of dry period }\end{array}$ & $\mathrm{n}$ & $\begin{array}{l}\text { Cows } \\
\text { removed }\end{array}$ & Reasons for removal \\
\hline $35 \mathrm{~d}$ & 35 & 9 & Incorrect dry period length $(n=6)$, metabolic disease ${ }^{1}(n=1)$ and clinical mastitis ${ }^{1}(n=2)$ \\
\hline $42 \mathrm{~d}$ & 37 & 3 & Died suddenly $^{2}(\mathrm{n}=1)$; incorrect dry period length $(\mathrm{n}=2)$ \\
\hline
\end{tabular}

${ }^{1}$ Cows were removed from the study plan in the first days of experiment and before calving.

${ }^{2}$ Sudden shock because of fast jugular administration of antibiotic by milking personnel at milking parlor.

${ }^{3}$ Severe lameness and inability to move.

Li et al., 1999). Therefore, the optimum length of the dry period may be shorter than previously considered. Indeed, recent animal experiments proposed that a 30 to $40-\mathrm{d}$ dry period is sufficient for maximizing the number of active differentiated secretory cells in cattle (Schairer, 2001; Bachman, 2002; Gulay et al., 2003; Annen et al., 2004; Rastani et al., 2005). The objective of this study was to determine whether shortening the dry period would affect performance and energy status of dairy cows.

\section{MATERIALS AND METHODS}

\section{Cows, Treatment, and Feeding}

The experiment was conducted between May and December of 2004. One hundred and twenty-two primiparous and multiparous Holstein cows were assigned to a completely randomized design with 56-, 42-, and 35$\mathrm{d}$ dry period lengths. Cows were selected for the study using the following criteria: 1) no clinical mastitis and SCC $<300,000$ cells; 2) days open $<200 \mathrm{~d}$; and 3) mean milk production $>20 \mathrm{~kg} / \mathrm{d}$. Experimental cows were not supplemented with bovine somatotropin. Actual dry period lengths for respective treatments (TRT) were 56 $\pm 5.1 \mathrm{~d}, 42 \pm 2.1 \mathrm{~d}$, and $35 \pm 2.7 \mathrm{~d}$. Fourteen cows were removed from the study; the reasons for animals leaving the study are presented in Table 1 . One hundred and eight cows were included for statistical analyses. All cows were inspected at dry-off by farm veterinarians and cows that had mastitis at that time, were removed from the experiment. Teat dipping was routinely performed at milking, and teats were sealed with teat sealer (Dry Flex, Solocup, Chicago, IL) after the last milking at dry-off. Milking machines (DeLaval, Tumba, Sweden) were evaluated routinely and maintained per the manufacturer's recommendation. Cows were housed in individual stalls and the conception status was confirmed by transrectal palpation. Cows were transitioned to special pens with deprivation of food for $24 \mathrm{~h}$ (abrupt cessation). Dry cows were housed in 2 pens: a far-off group (from 60 to $35 \mathrm{~d}$ before expected calving) and a close-up group, (35 d before expected calving) and barns were bedded with barley straw once daily. The management procedure followed in assigning cows to the 3 dry period lengths is summarized in Figure 1. Cows assigned to the 56- and 42-d TRT had 3 diet changes including late lactation diet to far-off diet, far-off diet to close-up diet, and close-up diet to early lactation diet (Figure 1), whereas cows in the $35 \mathrm{~d}$ TRT experienced only 2 diet changes (late lactation diet to close-up diet and close-up diet to early lactation diet; Figure 1). At the time of moving cows from the far-off to the close-up pen, cows were injected with 3,000 IU of vitamin $\mathrm{AD}_{3} \mathrm{E}$ (Nasr Pharmaceutical Co., Khorasan, Iran). Immediately after calving, cows were moved to the fresh-cow pen and fed the lactation ration. All cows were fed TMR formulated based on production level and gestation stage. In addition, they received wheat straw ad libitum during the dry and postpartum periods and had free access to water. Feed delivery was done 2 and 3 times a day at 0800 and $1700 \mathrm{~h}$, and 0600 , 1400 , and $2200 \mathrm{~h}$, respectively, for the dry period and postcalving. Further, all cows received mineral lick

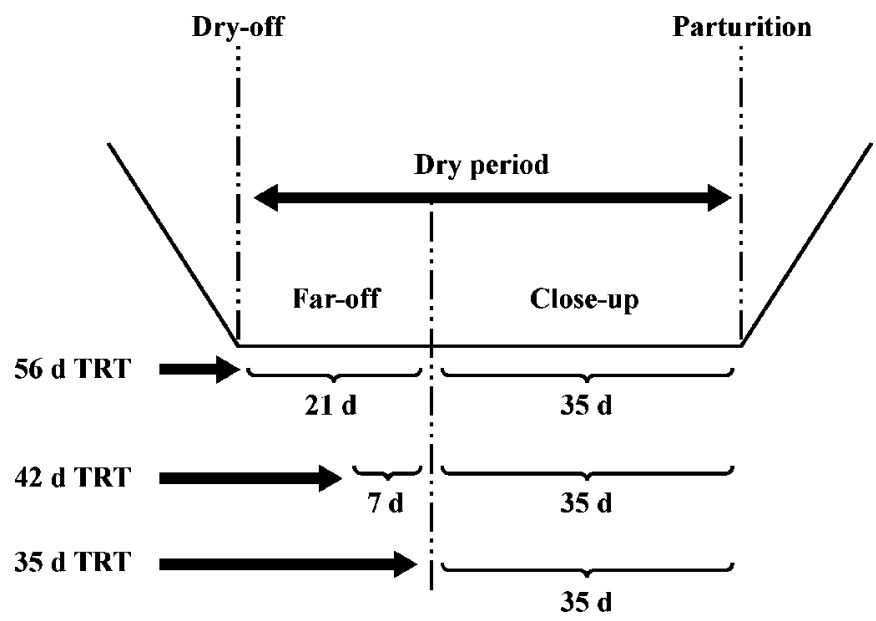

Figure 1. Management scheme of cows subjected to dry periods (treatments, TRT) of 35, 42, and $56 \mathrm{~d}$. Cows subjected to a 35-d treatment were transitioned to a close-up dry cow pen and fed a closeup ration at the time of milk stasis. After milk cessation, cows in the 42- and 56-d groups were transitioned to far-off dry cow pen until $35 \mathrm{~d}$ before expected calving date, and then transferred to the closeup pen and fed a close-up ration until calving. 
Table 2. Ingredient and chemical composition (DM basis) of TMR fed to Holsteins cows ${ }^{1}$

\begin{tabular}{|c|c|c|c|}
\hline Ingredient & $\begin{array}{l}\text { TMR for } \\
\text { fresh cows }\end{array}$ & $\begin{array}{l}\text { TMR for } \\
\text { far-off cows }\end{array}$ & $\begin{array}{c}\text { TMR for } \\
\text { close-up cows }\end{array}$ \\
\hline Alfalfa hay & 32.3 & 28.89 & 22.53 \\
\hline Corn silage & 19.08 & 23.64 & 28.53 \\
\hline Wheat straw & - & 22.77 & 10.17 \\
\hline Barley grain & 11.69 & 1.2 & 7.97 \\
\hline Corn grain & 8.45 & - & 4.83 \\
\hline Whole cottonseeds & 5.02 & - & 1.97 \\
\hline Cottonseed meal & 6.2 & 9.74 & 6.29 \\
\hline Whole soybeans & 0.56 & - & 5.19 \\
\hline Soybean meal & 5.89 & - & - \\
\hline Fish meal & 0.45 & - & 6.65 \\
\hline Fat supplement & 1.4 & - & - \\
\hline Rice bran & 0.87 & 11.82 & 1.32 \\
\hline Beet pulp & 4.89 & - & - \\
\hline Calcium carbonate & - & 0.16 & 0.88 \\
\hline Calcium sulphate & - & - & 0.37 \\
\hline Chloride sodium & - & 0.11 & - \\
\hline Magnesium oxide & - & 0.08 & - \\
\hline Gluten germ & 0.87 & 0.77 & 0.95 \\
\hline Urea & 0.1 & 0.11 & - \\
\hline Aluminum silicate & - & 0.27 & - \\
\hline Niacin & - & - & 0.04 \\
\hline Vitamin and mineral $\operatorname{mix}^{2}$ & 2.4 & 0.44 & 2.75 \\
\hline \multicolumn{4}{|c|}{ Chemical composition (\% DM basis) } \\
\hline $\mathrm{DM}$ & 51.3 & 53.1 & 51.6 \\
\hline $\mathrm{CP}$ & 18 & 14.48 & 15.51 \\
\hline $\mathrm{ADF}$ & 22.5 & 27.51 & 26.08 \\
\hline $\mathrm{NDF}$ & 40 & 47.72 & 42.15 \\
\hline $\mathrm{NFC}^{3}$ & 35.2 & 25.4 & 29.4 \\
\hline Ether extract & 4.2 & 3.37 & 2.91 \\
\hline $\mathrm{NE}_{\mathrm{L}}^{4}(\mathrm{Mcal} / \mathrm{kg})$ & 1.75 & 1.6 & 1.59 \\
\hline
\end{tabular}

\footnotetext{
${ }^{1}$ Feed samples were collected weekly. Analyses of components from Isfahan University of Technology (IUT) laboratory, Isfahan, Iran.

${ }^{2}$ Vitamin and mineral mixture (DM basis): 40,000 mg/kg Mn; 40,000 mg/kg Zn; $16,000 \mathrm{mg} / \mathrm{kg} \mathrm{Fe;} 12,000$ $\mathrm{mg} / \mathrm{kg} \mathrm{Cu} ; 640 \mathrm{mg} / \mathrm{kg} \mathrm{I} ; 240 \mathrm{mg} / \mathrm{kg}$ Se; $160 \mathrm{mg} / \mathrm{kg}$ Co; 4,000 kIU/kg vitamin A; $800 \mathrm{kIU} / \mathrm{kg}$ vitamin D; and $10 \mathrm{kIU} / \mathrm{kg}$ vitamin E.

${ }^{3} \mathrm{NFC}$ calculated as $100-[(\mathrm{NDF}-\mathrm{NDFCP})+\mathrm{CP}+$ ether extract + ash $](\mathrm{NRC}, 2001)$.

${ }^{4}$ Calculated according NRC (2001).
}

blocks (Shirindaneh, Shiraz, Iran) to meet mineral requirements.

\section{Body Condition Scoring}

Body condition score was recorded 3 times during the experiment: at dry-off, calving, and at $15 \mathrm{wk}$ of lactation. The same assessor assigned BCS to each cow on a scale of 1 (emaciated cows) to 5 (severely overconditioned; Lowman et al., 1976) with 0.25-unit increments. The method was based on a visual and tactile appraisal of body fat reserves in the back and pelvic regions.

\section{Sample Collection}

Feed Samples. Feed samples were collected weekly and stored in plastic bags at $-20^{\circ} \mathrm{C}$ until analysis. Feed samples were analyzed for CP, ether extract, ash, DM,
$\mathrm{ADF}$, and NDF. These measurements were used for estimating $\mathrm{NE}_{\mathrm{L}}$ (NRC, 2001). For prepartum diets, $\mathrm{NE}_{\mathrm{L}}$ (Mcal/kg) was computed based on a cow weighing 650 $\mathrm{kg}$ and consuming $11.5 \mathrm{~kg}$ of DM/d (NRC, 2001). Constituents and composition of feeds are summarized in Table 2.

Blood Samples. Approximately $10 \mathrm{~mL}$ of blood was sampled from each cow 1 wk before expected calving and immediately after parturition. Precalving blood specimens were collected after the morning feeding from the coccygeal vein and placed in Vacutainer tubes without anticoagulant (Vacutainer, Becton-Dickinson, Franklin Lakes, NJ). Samples were allowed to clot and kept cold on ice until they were transferred to the laboratory and centrifuged at $1,850 \times g$ for $20 \mathrm{~min}$ at $4^{\circ} \mathrm{C}$ within $2 \mathrm{~h}$ of blood collection for the separation of serum. Serum was harvested, and each sample was divided into 3 aliquots and stored at $-20^{\circ} \mathrm{C}$ for further analyses. 
Milk Samples and Records. Quarter milk samples $(50 \mathrm{~mL})$ were collected weekly at 3 consecutive milkings $(0500,1300$, and $2100 \mathrm{~h})$ until the eighth week of lactation. Collected samples were analyzed for milk fat, protein, and SCC (Fossomatic 5000, Foss Electric, Hillerød, Denmark). Before parturition, the 35- and 42-d TRT had 21 and 7 additional DIM, respectively because of extending the previous lactation period (see Figure 1). Cows in these TRT were milked 3 times daily until dryoff, and total additional milk yield was recorded daily for each TRT separately. Also, previous lactation and dry-off-day milk yields were recorded and used as a covariate in data analysis. Average daily milk production of cows in the previous lactation (until $60 \mathrm{~d}$ before parturition; i.e., before assigning the cows in TRT) was used as a covariate for 3 to 210 DIM milk production analyses. Beginning $3 \mathrm{~d}$ after parturition, milk yield produced by all cows was recorded daily through 210 $\mathrm{d}$ of lactation.

\section{Chemical Analyses}

Quantification of NEFA, Triglyceride, and Glucose in Blood. Nonesterified fatty acids (NEFA-C, Wako Chemicals USA, Inc., Richmond, VA; Custer et al., 1983) concentrations were measured using colorimetric enzymatic reactions with an automated wet chemistry analyzer (Hitachi 917, Roche Diagnostics, Indianapolis, IN). The analyzer was calibrated and controls assayed daily according to the manufacturer's instructions to ensure acceptable assay performance. Total plasma triglyceride concentrations were measured by using spectrophotometric analysis and a commercially available enzymatic kit (Sigma Chemical, St. Louis, MO). Serum glucose samples were analyzed by using a commercial kit (kit Trinder, Sigma Chemical Co.; Trinder, 1969).

Quantification of IGF-I and Insulin in Blood. Insulin-like growth factor I was measured by doubleantibody immunoradiometric assays using reagents from Immunotech (Marseille, France). The protocol for the IGF-I assay included an acid-ethanol extraction step to release IGF-I from its binding proteins. To control the quality, analytical batches systematically included 3 standard sera. The intraassay coefficient of variation was $5.5 \%$; the interassay coefficient of variation was $9.7 \%$. Serum insulin concentration was measured by RIA (Hales and Randle, 1963). The intraassay coefficient of variation was $5.8 \%$; the interassay coefficient of variation was $4.9 \%$.

\section{Reproduction and Health Disorders}

During lactation, cows were monitored for estrus by milking personnel at milking time and by experienced herdmen. After detection of estrus, cows were inspected by herd veterinarians; those that did not have any reproductive disease were inseminated utilizing the a.m/ p.m rule (Morton, 2004). Pregnancy confirmation tests were performed $60 \mathrm{~d}$ after insemination by rectal palpation. Reproductive records maintained included days open, services per conception, first-service conception, days to first service, and pregnancy rate, and were obtained within 4 mo after parturition for all cows. The pregnancy rate was defined as the total cows diagnosed as pregnant in each TRT over total cows multiplied by 100 .

Technicians visited the herd every day and recorded health status, and records were verified by herd veterinarians. Dystocia (veterinarian-assisted calving and delay in second phase of calving), mastitis (inflammation and infection of the udder), displaced abomasums (movement of the abomasums to the left and bottom of the rumen), and retained placenta (failure in removing the fetal membranes $24 \mathrm{~h}$ after calving) were defined as disorders characterized in this experiment.

\section{Statistical Analyses}

Daily milk yields were collapsed into weekly means, and were then subjected to statistical analyses. Yields were extended to $305 \mathrm{~d}$ of lactation and corrected based on previous 305-d milk yield. The PROC MIXED procedure of SAS (SAS Institute, 1999) was used to analyze milk yield and composition, BCS, and reproduction and metabolic status data as a completely randomized design with repeated measurements. The model used to analyze the data included the fixed effects of dry period length, parity, time, 3-way interaction terms of fixed effects, the random effect of cow nested within treatment, and the residual errors. Far-off milk yield was considered as a covariate for postcalving SCC yield, because previous experiments have indicated that faroff milk yield can affect milk SCC yield (Rajala-Schultz et al., 2005). The significant difference level was set as $P<0.05$.

\section{RESULTS}

\section{BCS Changes}

The effect of TRT on BCS is shown in Table 3. Cows in the 35-d TRT had greater BCS than those in the 56$\mathrm{d}$ TRT at dry-off $(P=0.02)$. At calving, no TRT differences in BCS were detected. The BCS changes was greater for the 42 -d $(P=0.03)$ and $56-\mathrm{d}(P=0.02)$ TRT compared with the $35-\mathrm{d}$ TRT in the prepartum period, but did not differ in the postpartum period among TRT (Table 3). Postpartum, the 35-d TRT demonstrated a 
Table 3. Effects of different dry period lengths on BCS of Holstein cows

\begin{tabular}{|c|c|c|c|c|c|c|c|c|c|c|}
\hline \multirow{3}{*}{$\begin{array}{l}\text { BCS } \\
\text { measurement }^{1}\end{array}$} & \multirow{2}{*}{\multicolumn{3}{|c|}{ Dry period length }} & \multirow[b]{3}{*}{$P$-value } & \multicolumn{6}{|c|}{ Contrasts } \\
\hline & & & & & \multicolumn{2}{|c|}{35 vs. $42 \mathrm{~d}$} & \multicolumn{2}{|c|}{35 vs. $56 \mathrm{~d}$} & \multicolumn{2}{|c|}{42 vs. $56 \mathrm{~d}$} \\
\hline & $35 \mathrm{~d}$ & $42 \mathrm{~d}$ & $56 \mathrm{~d}$ & & SEM & $P$-value & SEM & $P$-value & SEM & $P$-value \\
\hline BCS 1 & 3.22 & 3.11 & 2.98 & 0.06 & 0.098 & 0.26 & 0.100 & 0.02 & 0.098 & 0.19 \\
\hline BCS 2 & 3.22 & 3.24 & 3.14 & 0.54 & 0.099 & 0.77 & 0.100 & 0.44 & 0.098 & 0.28 \\
\hline BCS 3 & 2.96 & 2.84 & 2.69 & 0.27 & 0.169 & 0.46 & 0.169 & 0.09 & 0.171 & 0.38 \\
\hline BCS $2-$ BCS 1 & -0.002 & +0.135 & +0.137 & 0.04 & 0.062 & 0.03 & 0.063 & 0.02 & 0.063 & 0.97 \\
\hline BCS 3 - BCS 2 & -0.292 & -0.286 & -0.445 & 0.50 & 0.157 & 0.98 & 0.157 & 0.30 & 0.159 & 0.32 \\
\hline
\end{tabular}

${ }^{1} \mathrm{BCS} 1$ = BCS at drying-off day; BCS 2 = BCS at calving day; BCS 3 = BCS at 15 wk of lactation; measured on a 5-point scale, from emaciated (score $=1$ ) to severely over-conditioned (score $=5$ ) cows (Lowman et al., 1976).

tendency $(P=0.092)$ for increased BCS compared with the 56-d TRT by wk 15 of lactation.

\section{Milk Yield}

Milk yield data are presented in Table 4 and Figure 2 (A and B). The effect of week was significant among TRT $(P=0.0001)$. When pre- and postpartum milk yields were analyzed separately, there were differences in average daily postpartum milk yields among dry period lengths, regardless of parity $(34.75,34.56$, and $36.15 \mathrm{~kg} / \mathrm{d}$ for cows in the $35-, 42-$, and 56-d TRT, respectively; $P=0.0001$ ). From 3 to 210 DIM, no differences in daily milk production of the multiparous cows in the 35- and 56-d TRT were observed, even when adjusted for 305-d lactation milk yield (Table 4). Likewise, no differences were detected between the 305-d adjusted milk yields when primiparous and multiparous cows assigned to the 35-d TRT were compared with each other. Multiparous cows in the 42-d TRT produced less daily milk compared with those in the $56-(P=0.021)$ or 35-d $(P=0.004)$ TRT (Table 4$)$. Among multiparous cows, differences existed at wk $29(P=0.049)$ for 35 vs. 56-d TRT and at wk $22(P=0.027)$ for $42-$ vs. 56 -d TRT (Figure 2B). Additionally, weekly postpartum milk production changes tended to be significant between the 35- and 42-d TRT at wk $6(P=0.07), 10(P=0.081)$, $12(P=0.088)$, and $22(P=0.07)$, and at wk $5(P=$ $0.082)$ and $23(P=0.096)$ for the $56-$ vs. $42-d$ TRT (Figure 2B). Milk yield increased during the first $2 \mathrm{wk}$ of lactation in all TRT (Figure 2B). Subsequently, cows reached peak milk yield between wk 7 to 10 (Figure 2B). Multiparous cows in the 35 -d TRT showed a reduction in milk production at wk $28(P=0.045$; Figure $2 \mathrm{~B})$. In the present study, multiparous cows in the 35-d TRT had greater reduction in milk yield than those in the 56-d TRT around wk 29 and $30(P=0.049$; Figure 2B). Among primiparous animals, the average milk production of the 35-d TRT was lower than that of the 56$\mathrm{d}$ TRT $(P=0.0001)$ and this difference remained even after adjusting milk yield for 305-d lactation (Table 4). The difference in daily milk yield of primiparous cows in the 35- and 56-d TRT declined after adjusting milk yield for a 305 -d lactation $(P=0.001)$. Primiparous cows in the 42-d TRT produced less milk than those in the 56-d TRT $(P=0.0001)$; however, the former produced more mean daily milk than primiparous cows in the 35-d TRT $(P=0.005)$. Differences existed at wk $9(P=$ $0.049), 10(P=0.019), 11(P=0.033)$, and $30(P=0.048)$

Table 4. Milk production (kg) of Holstein cows given different dry period lengths $(35,42 \text {, and } 56 \mathrm{~d})^{1}$

\begin{tabular}{|c|c|c|c|c|c|c|c|c|}
\hline Variable & \multicolumn{2}{|c|}{$35 \mathrm{~d}$} & \multicolumn{2}{|c|}{$42 \mathrm{~d}$} & \multicolumn{2}{|c|}{$56 \mathrm{~d}$} & SEM & $P$-value \\
\hline 210 DIM (adjusted) ${ }^{2}$ & $33.74^{\mathrm{a}}$ & $35.42^{\mathrm{b}}$ & $35.1^{b}$ & $34^{\mathrm{a}}$ & 37.12 & $35.18^{\mathrm{b}}$ & 0.49 & 0.0001 \\
\hline Drying-off day & $18.07^{\mathrm{ab}}$ & $14.23^{\mathrm{a}}$ & 23.58 & $17.08^{\mathrm{ab}}$ & $22.09^{b c}$ & $21.04^{\mathrm{b}}$ & 2.80 & 0.39 \\
\hline $305-\mathrm{d}(\text { adjusted })^{3}$ & $10,564^{\mathrm{a}}$ & $11,202^{\mathrm{ab}}$ & $10,656^{\mathrm{a}}$ & $10,264^{\mathrm{a}}$ & $11,918^{\mathrm{b}}$ & $10,849^{\mathrm{ab}}$ & 661 & 0.17 \\
\hline
\end{tabular}

${ }^{\mathrm{a}-\mathrm{c}}$ Means within rows with different superscript letters differ $(P<0.05)$.

${ }^{1}$ Milk production was recorded daily in three consecutive milking for each cow from 3 through 210 DIM.

${ }^{2} 210$ DIM represents the average daily milk yield of cows from 3 to 210 DIM. Average daily milk production of cows in previous lactation (until $60 \mathrm{~d}$ before parturition) was used as a covariate. Multiparous cows in $35 \mathrm{~d}$ treatment (TRT) produced an additional $285.5 \mathrm{~kg}$ of milk compared with multiparous and primiparous cows in $56 \mathrm{~d}$ TRT.

${ }^{3}$ Previous lactation 305-d milk yield is considered as a covariate. 


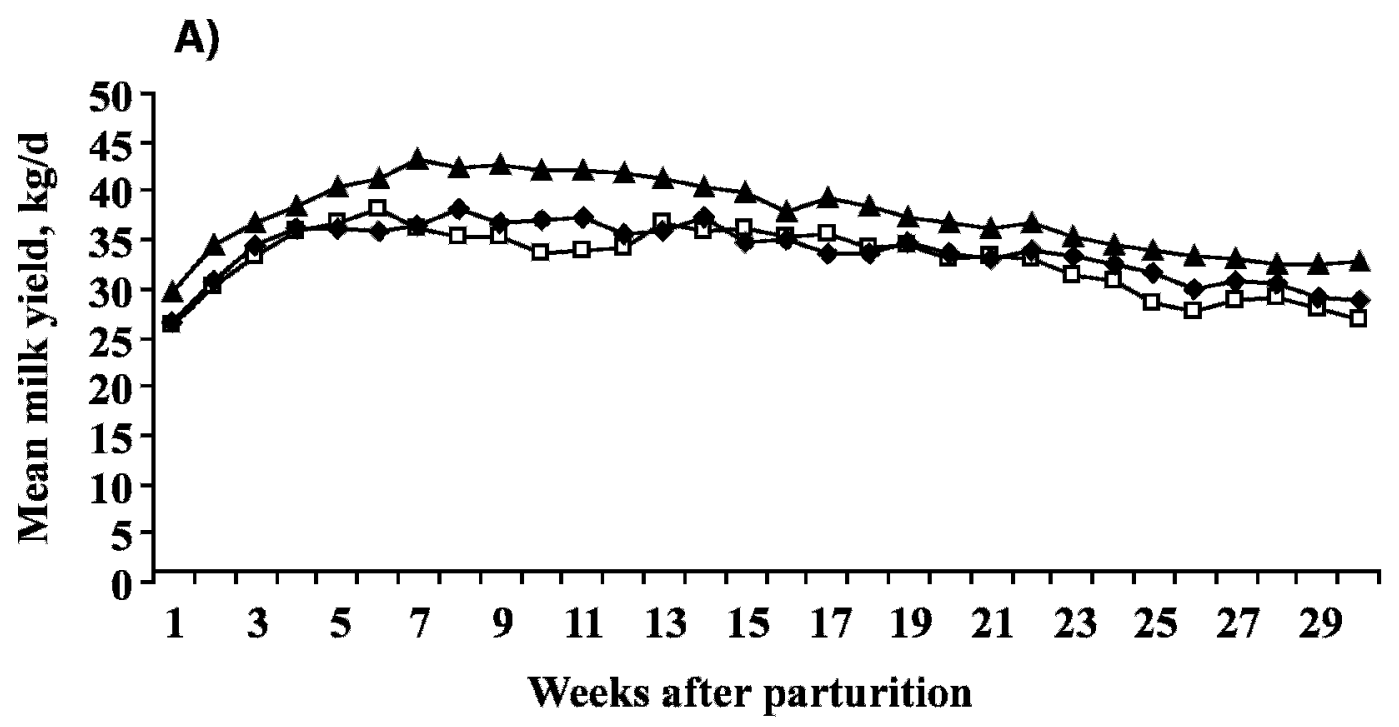

B)

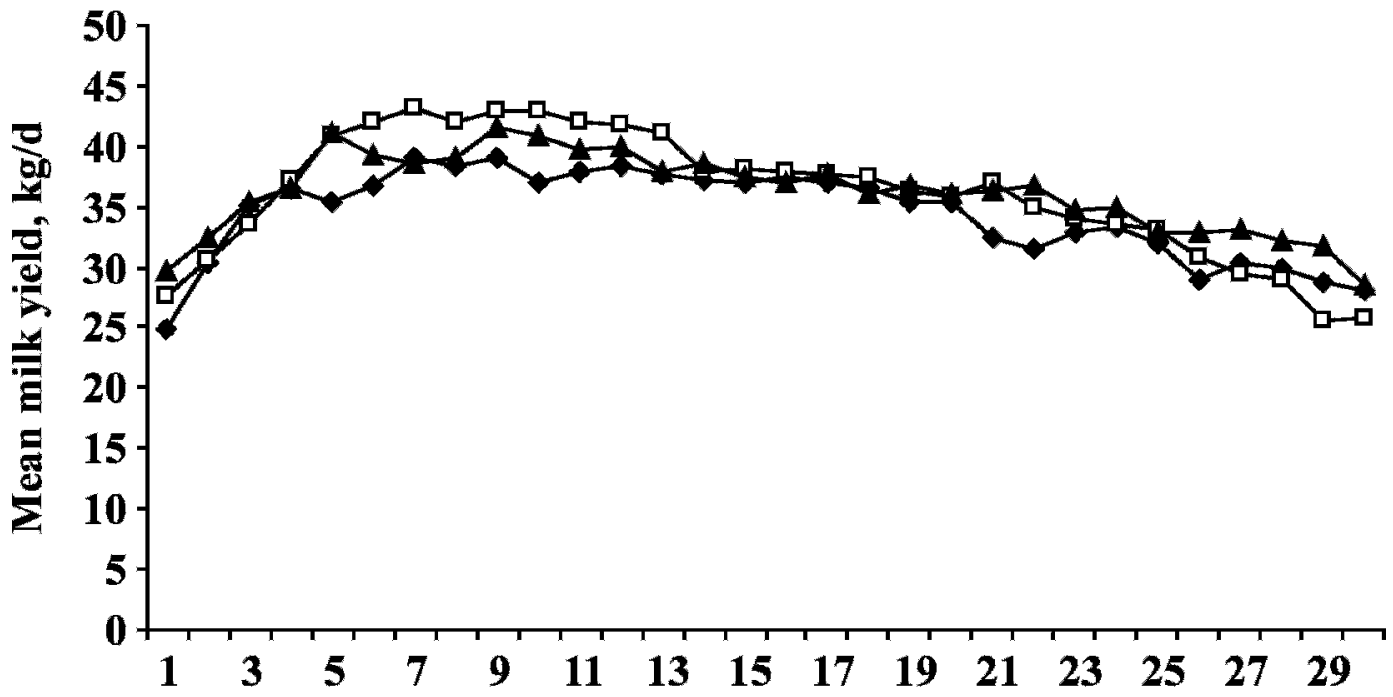

Weeks after parturition

Figure 2. A) Daily milk production (kg/d) in primiparous Holstein cows assigned to different dry period lengths. Treatments are 35-d $(\square), 42-\mathrm{d}(\bullet)$, and 56-d $(\boldsymbol{\Delta})$ dry periods. Fifty-five primiparous cows were subjected to the different dry period lengths, and their postpartum daily milk yields $(\mathrm{kg} / \mathrm{d})$ were collapsed into weekly means. Differences were observed at wk $9(P=0.049), 10(P=0.019), 11(P=0.033)$, and $30(P=0.048)$ for 56 -d vs. $35-d$ cows, and at wk $7(P=0.041)$ for 56 -d vs. 42 -d cows. B) Daily milk production (kg/d) in multiparous Holstein cows assigned to different dry period lengths. Treatments are 35-d ( $\square$ ), 42-d $(\diamond)$ and 56-d (ム) dry periods. Fifty-three multiparous cows subjected on the different dry period lengths, and their postpartum daily milk yields $(\mathrm{kg} / \mathrm{d})$ were collapsed into weekly means. Differences were observed at wk $22(P=0.027)$ for 56 -d vs. 42 -d cows, and at wk $29(P=0.049)$ for 56 -d vs. $35-d$ cows.

for the 35-d vs. 56-d TRT, and at wk $7(P=0.041)$ for the 42-d vs. 56-d TRT (Figure 2A).

As expected the multiparous cows in the 35-d TRT produced a greater amount of daily milk than did the primiparous cows in the same TRT $(P=0.0009$; Table 4$)$.

\section{Milk Composition}

Milk composition percentage and yield of different TRT were compared in the first 8 wk of lactation, and data are presented in Table 5. Neither milk fat percentage nor yield was affected by shortening the dry period. Likewise, no differences were observed in milk protein percentage across TRT (Table 5). Cows in the 35- and 56 -d TRT differed in milk protein yields $(1.06 \pm 0.07$ vs. $1.24 \pm 0.07 \mathrm{~kg} / \mathrm{d}$ respectively; $P=0.048$ ). Further, among primiparous cows, milk protein yield was greater for cows in the 56-d TRT than in the 35-d TRT cows $(P=0.05$; Table 5$)$. 
Table 5. Milk composition of Holstein cows given different dry period lengths $(35,42 \text {, and } 56 \mathrm{~d})^{1}$

\begin{tabular}{|c|c|c|c|c|c|c|c|c|}
\hline \multirow[b]{2}{*}{ Variable } & \multicolumn{2}{|c|}{$35 \mathrm{~d}$} & \multicolumn{2}{|c|}{$42 \mathrm{~d}$} & \multicolumn{2}{|c|}{$56 \mathrm{~d}$} & \multirow[b]{2}{*}{ SEM } & \multirow[b]{2}{*}{$P$-value } \\
\hline & Primiparous & Multiparous & Primiparous & Multiparous & Primiparous & Multiparous & & \\
\hline Milk protein yield $(\mathrm{kg} / \mathrm{d})$ & $0.99^{\mathrm{a}}$ & $1.1^{\mathrm{ab}}$ & $1.14^{\mathrm{ab}}$ & $1.00^{\mathrm{ab}}$ & $1.29^{b}$ & $1.19^{\mathrm{ab}}$ & 0.14 & 0.40 \\
\hline Milk fat (\%) & 3.60 & 3.96 & 3.68 & 3.53 & 3.43 & 3.79 & 0.51 & 0.70 \\
\hline Milk fat yield $(\mathrm{kg} / \mathrm{d})$ & 1.23 & 1.45 & 1.27 & 1.18 & 1.29 & 1.43 & 0.19 & 0.54 \\
\hline Adjusted $\mathrm{SCC}^{2}(\times 1,000)$ & $279.8^{\mathrm{a}}$ & $371.5^{\mathrm{a}}$ & $272.9^{\mathrm{a}}$ & $777.7^{\mathrm{b}}$ & $476.6^{\mathrm{ab}}$ & $320.5^{\mathrm{a}}$ & 263 & 0.12 \\
\hline
\end{tabular}

${ }^{\mathrm{a}, \mathrm{b}}$ Means within rows with different supserscript letters differ $(P<0.05)$.

${ }^{1}$ Milk samples were collected weekly until $8 \mathrm{wk}$ of lactation and samples were used for milk composition analyses.

${ }^{2} \mathrm{SCC}$ is adjusted based on drying-off milk yield.

Milk SCC was greater for multiparous cows in the 42-d TRT compared with those in the 35- and 56-d TRT (Table 5). Combined across parities, no difference was detected among the 3 TRT for SCC.

\section{Metabolic Status}

NEFA and Triglyceride in Blood. Prepartum NEFA were different between primiparous cows subjected to the 35 - and 56-d TRT (349.0 \pm 30.3 vs. 422.4 $\pm 25.9 \mu \mathrm{Eq} / \mathrm{L}$, respectively; $P=0.044$ ), and a tendency toward a parity $\times$ dry period length interaction during late pregnancy showed that a part of this resulted from a decrease in the late pregnancy plasma NEFA concentration for cows in the 35-d -vs. 56-d TRT cows. We did not detect any differences for prepartum NEFA between multiparous cows in the 35- and 56-d TRT (375.3 $\pm 21.0 \mathrm{vs} .324 \pm 34.4 \mu \mathrm{Eq} / \mathrm{L}$ for 35 and $56 \mathrm{~d}$, respectively). Subsequently, primiparous cows in the 56-d TRT had a greater concentration of serum NEFA than did the cows in the 35 -d TRT $(419.2 \pm 25.1$ vs. $348.5 \pm 30.0$ $\mu \mathrm{Eq} / \mathrm{L}$ for 56 and 35-d TRT, respectively; $P=0.045$ ). Comparison of the serum NEFA among cows in other TRT did not reveal any differences. Importantly, we did not observe differences between primiparous and multiparous cows assigned to the 35-d TRT at any time for serum NEFA concentration.

Regardless of parity, we failed to detect any effects of dry period length on prepartum triglyceride (33.02, 29.73 , and $34.30 \mathrm{mg} / \mathrm{dL}$ for $35-$, 42-, and 56-d TRT, respectively) or postpartum triglyceride (30.61, 28.02, and $31.04 \mathrm{mg} / \mathrm{dL}$ for $35-, 42-$, and $56-\mathrm{d}$ TRT, respectively). As expected for serum triglycerides, there was a difference due to parity in the 35-d TRT both in late pregnancy $(27.3 \pm 2.30$ and $38.7 \pm 3.30 \mathrm{mg} / \mathrm{d}, P=0.007)$ and early lactation $(26.38 \pm 1.96$ and $34.85 \pm 3.03 \mathrm{mg} / \mathrm{dL}$, $P=0.03$ ) between multiparous and primiparous cows.

IGF-I, Insulin, and Glucose in Blood. No parity effects were detected for serum glucose, insulin, or IGFI concentration because of a reduction in dry period length. We also observed no differences in prepartum and postpartum glucose concentrations among the TRT $(72.45 \pm 1.35,72.59 \pm 1.46$, and $74.35 \pm 1.58 \mathrm{mg} / \mathrm{dL}$ prepartum and $80.17 \pm 3.2,74.6 \pm 2.9$, and $78.35 \pm 2.9$ $\mathrm{mg} / \mathrm{dL}$ postpartum, for cows in the $35-, 42-$, and 56-d TRT, respectively). There were no postpartum differences in serum insulin $(10.67 \pm 1.99,11.61 \pm 2.63$, and $10.14 \pm 2.26 \mu \mathrm{IU} / \mathrm{mL})$ and IGF-I $(178.2 \pm 20.9,157.2 \pm$ 19.3 , and $136.4 \pm 19.3 \mathrm{ng} / \mathrm{mL}$ ) concentrations for cows in the 35-, 42-, and 56-d TRT, respectively. Postpartum serum IGF-I concentration tended to be greater for cows on the 35-d TRT compared with those on the 56-d TRT $(P=0.083)$.

\section{Reproductive Measurements and Selected Health Disorders}

The incidence of selected health disorders and reproductive performance data are presented in Tables 6 and 7 , respectively. Pregnancy rate was greater $(P=0.041)$ for multiparous cows (71\%) than primiparous cows (48\%) assigned to the 35-d TRT. No difference in pregnancy rate occurred among other TRT. Among primiparous cows, the $42-d$ TRT had increased $(P=0.042)$ days open ( $121 \mathrm{~d}$ ) compared with the 56-d TRT ( $85 \mathrm{~d}$ ). Days open data were consistent across the rest of TRT. Days to first service ranged from 46 to $57 \mathrm{~d}$ and did not differ across the TRT. There were fewer services per conception ( 2.0 vs. 3.0 respectively; $P=0.026$ ) in multiparous cows in the 35-d TRT than those in the 42-d TRT. First-service conception rate was greater $(P=0.021)$ in

Table 6. The effect of dry period lengths (35, 42, and $56 \mathrm{~d}$ ) on incidence of selected metabolic disorders ${ }^{1}$

\begin{tabular}{llll}
\hline Item & $35 \mathrm{~d}$ & $42 \mathrm{~d}$ & $56 \mathrm{~d}$ \\
\hline Dystocia & $3 / 35$ & $2 / 37$ & $3 / 36$ \\
Clinical mastitis at calving & $3 / 35$ & $1 / 37$ & $1 / 36$ \\
Clinical mastitis during next lactation & $9 / 35$ & $6 / 37$ & $5 / 36$ \\
Displaced abomasum & $1 / 35$ & $1 / 37$ & $1 / 36$ \\
Retained placenta & $5 / 35$ & $3 / 37$ & $7 / 36$ \\
\hline
\end{tabular}

${ }^{1}$ Technicians visited the herd every day and recorded identification number of affected cows and date of diagnosis during the experiment. 
Table 7. Summary of reproductive measurements in cows assigned to different dry period lengths $(35,42 \text {, and } 56 \mathrm{~d})^{1}$

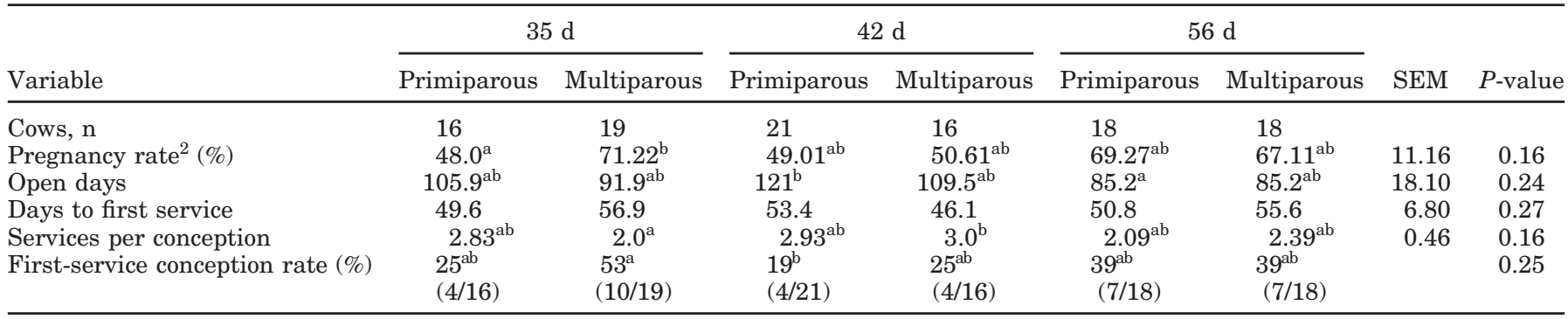

${ }^{\mathrm{a}, \mathrm{b}}$ Means within rows with different superscript letter differ $(P<0.05)$.

${ }^{1}$ Data were collected until 4 mo of lactation for all treatments.

${ }^{2}$ Pregnancy rate defined as the percentage of pregnant cows in a treatment.

multiparous cows in the 35-d TRT (53\%) compared with primiparous cows in the 42-d TRT (19\%). Regardless of parity, no clear main effects were found on binomial reproductive measurements between cows in the 35and 56-d TRT. Pregnancy rate was reduced $(P=0.038)$ in cows in the 42 -d TRT $(49.76 \pm 5.6 \%)$ compared with cows in the 56-d TRT $(66.77 \pm 5.7 \%)$, with cows in the 35-d TRT being intermediate. Services per conception were greater $(P=0.029)$ in cows in the 42 -d TRT $(2.78$ $\pm 0.22 \mathrm{~d}$ ) compared with those in the 56-d TRT (2.06 \pm $0.23 \mathrm{~d})$ and tended to be fewer $(P=0.067)$ in cows in the $35-\mathrm{d}$ TRT $(2.20 \pm 0.21 \mathrm{~d})$ compared with those in the 42-d TRT.

\section{DISCUSSION}

It is likely that extremely short dry periods do not provide optimum time for mammary cell turnover, leading to decreased milk yield during the next lactation (Capuco et al., 2003; Annen et al., 2007). Postcalving BCS changes demonstrated that cows given short dry periods experienced less negative energy balance than cows with longer dry periods (Table 3), presumably because of greater feed intake. Similar to these results, reduction in BCS loss after parturition by giving short dry periods is reported by others (Swanson, 1965; Farries and Hoheisel, 1989; Gulay et al., 2003). Rastani et al. (2005) and Gulay et al. (2005) demonstrated that BCS at calving was similar among experimental groups (28-d vs. 56-d and 30-d vs. 70-d dry periods, respectively), but Rastani et al. (2005) found that postcalving BCS loss for the 56-d dry period group was greater than that of 28-d dry period group.

Multiparous cows in the 35-d TRT produced more milk than primiparous cows in the same TRT during the whole lactation (Table 4). This, coupled with nonsignificant differences in previous lactation milk yield of the 35 -d TRT $(9,295 \pm 636$ vs. $10,661 \pm 587 \mathrm{~kg}$ for primiparous cows vs. multiparous cows, respectively), supports the notion that primiparous cows are very sensi- tive to a short dry period ( $35 \mathrm{~d}$ ). The lower milk production in primiparous cows given a short dry period may therefore be attributable to delay in mammary growth, depression of mammary gland function, or a combination of both. All TRT demonstrated similar milk yield trends during the first $30 \mathrm{wk}$ of lactation, but primiparous cows subjected to the 35 -d TRT demonstrated less milk production at wk 9,10 , and 11 than did those in the 56-d TRT (Figure 2A). This was similar to the findings reported by Annen et al. (2004). Moreover, this observation supports the fact that milk reduction of primiparous cows in the 35-d TRT occurs in early lactation rather than in later stages of lactation (Figure 2A). We speculate that short dry periods do not provide sufficient time for cell turnover, especially in primiparous cows. Our findings agree with those of others (Wilton et al., 1967; Gulay et al., 2003; Annen et al., 2004). Discrepancies in results of different studies on interaction of dry period length and parity apparently arise from management schemes (Gulay et al., 2005; Rastani et al., 2005), genetic potential of milk yield (Rastani et al., 2005), experimental method (between-cow model or within-cow and half-udder model) and statistical power. Because of high variation for milk yield in early lactation, it is important to evaluate the statistical power of these types of experiments before they are conducted.

There was no difference in average daily milk yield between multiparous cows in the 35- and 56-d TRT (Table 4). This is in agreement with the results of other studies (Gulay et al., 2003, 2005; Annen et al., 2004; Rastani et al., 2005). In addition, multiparous cows in the 35-d TRT produced additional milk because of extension of the previous lactation cycle in the present study (Figure 1). In this study, multiparous cows in the 35-d TRT produced an additional $285.5 \mathrm{~kg}$ of milk compared with multiparous and primiparous cows in the 56-d TRT. Other authors (Bachman, 2002; Gulay et al., 2003; Rastani et al., 2005) reported additional milk between 400 to $550 \mathrm{~kg}$ for cows in a 30-d dry period 
group compared with those of a conventional dry period. Lower milk production of multiparous cows assigned to the 42-d TRT in comparison with the 35- and 56-d TRT cows is hypothesized to be due to nutritional stress (Table 4). Frequent diet changes may lead to reduction in DMI of cows, subsequently resulting in negative energy balance (Grummer and Rastani, 2004). Cows in the 42-d TRT were removed from the far-off pen to the close-up pen within a very short period ( $7 \mathrm{~d}$, Figure 1 ). This could result in more stressful condition of cows in the 42-d TRT than in the other 2 TRT. Surprisingly, cows in the 35-d TRT were less productive compared with those in the 42-d TRT. Multiparous cows in all TRT did not differ in peak or average milk yields for the first $30 \mathrm{wk}$ of lactation. Results from milk yield data support the argument that shortening the dry period in multiparous cows has no negative effect on milk yield (Table 4 and Figure 2B).

In the current study, shortening the dry period affected 305-d milk yield (adjusted for previous lactation milk yield) in primiparous cows, but not in multiparous cows (Table 4), which is similar to results reported by others (Makuza and McDaniel, 1996; Bachman, 2002; Gulay et al., 2003). Bachman (2002) reported that there was no difference in subsequent 305-d lactation milk yield of multiparous cows with 57.3- and 33.9-d dry period lengths. In the present study, cows in the 35-d TRT produced $501 \mathrm{~kg}$ more milk compared with those in the 56-d TRT during $305 \mathrm{~d}$ of lactation.

In this study, milk fat percentage and fat yield were unaffected by dry period length (Table 5). This is similar to other studies (Lotan and Adler, 1976; Gulay et al., 2003; Annen et al., 2004, Rastani et al., 2005). Milk protein percentage did not differ among dry period TRT (Table 5), which is in agreement with other studies (Smith et al., 1967; Gulay et al., 2003). Sørensen and Enevoldson (1991) reported more milk protein yield for cows with a 49-d dry period length compared with a 28-d dry period length; this was similar to the results in the current study (Table 5). Gulay et al. (2003) and Rastani et al. (2005) reported no differences in milk protein yield for cows in 30- and 60-d dry periods. Different amounts of milk protein yield between primiparous cows in the 35- and 56-d TRT may be explained by a reduced milk yield capacity for cows in the 35-d TRT. The SCC of milk differed across TRT, but this difference was not consistent across the dry period TRT (Table 5). Our results in this experiment are in agreement with others, confirming that, regardless of parity, length of dry period has no effect on SCC of milk (Sørensen and Enevoldsen, 1991; Gulay et al., 2003; Rastani et al., 2005). Others (Chilliard, 1999; Annen et al., 2004) reported a tendency toward increased SCC when the dry period was shortened or omitted. The main reason for this discrepancy may be the limited time of antibiotic therapy in shortest dry period group. Results were not consistent with our hypothesis that milk SCC content would be changed among TRT because of substantial difference of dry-off milk production among TRT (Table 4). In agreement with our results, Natzke et al. (1975) reported no clear effect of dry-off milk yield on IMI rates.

Primiparous cows in the 35-d TRT produced less milk (Table 4) and for this reason were likely in better energy balance than cows in the other TRT. Lower concentrations of pre- and postcalving serum NEFA could be associated with less nutritional stress, more stable rumen flora, and less milk production in the 35-d TRT compared with primiparous cows in the 56-d TRT. Milk yield was the most important key factor controlling the energy balance. In contrast to our study, neither prepartum nor postpartum NEFA concentrations were different between cows in 30- and 60-d dry period lengths in previous studies (Lotan and Adler, 1976; Rastani et al., 2005). This discrepancy may be attributed to interaction of dry period length and parity, which must be taken into account when metabolic status of cows is studied.

Lower concentration of serum triglycerides reflects a greater content of liver triglyceride (Grummer, 1993), which is associated with negative energy balance and occurrence of other metabolic disorders and infectious diseases in early lactation (Herdt, 1992). The lower concentrations of serum triglyceride in multiparous cows in the 35-d TRT, compared with primiparous cows in the same TRT, led to our conclusion that primiparous cows in the 35-d TRT may experience less negative energy balance. Because long-chain $\beta$-oxidation capacity of liver is one of the important factors controlling the infiltration concentrations of triglyceride in liver and its release to the blood flow (Emery et al., 1992), further studies are needed to evaluate the impact of short dry periods on liver composition of primiparous and multiparous cows.

Our data are in agreement with the observations of Rastani et al. (2005) who reported no difference in prepartum serum glucose between 28- and 56-d dry period lengths. The current study presents new information regarding the effects of a short dry period on serum IGFI and insulin concentrations. Serum or plasma IGF-I is one of the most important factors controlling mammary proliferation and apoptosis during the dry period (Accorsi et al., 2002).

Our study supports the concept that nutritional management strategies during the prepartum period, along with dry period length, play a critical role in reproductive status of dairy cows during the subsequent lactation. The less efficient reproductive status of cows as- 
signed to the 42-d TRT may be contributed to the frequent and sudden diet changes during the dry period (Figure 1). Our results indicate that shortening the dry period in addition to making minimum changes in diet composition during the dry period could be an appropriate solution for improving reproduction in subsequent lactation. Our results are in agreement with those of Gumen et al. (2005) who reported similar firstservice conception and pregnancy rates, services per conception, and days open for cows with 28- and 56-d dry periods. Lotan and Adler (1976) and Annen et al. (2004) did not make statistical comparisons, but they reported an apparent similarity of pregnancy rate and services per conception between cows with traditional (60-d) and short (30-d) dry periods. Further studies are needed for accurate evaluation of the relationship between short dry periods and cow's reproductive performance.

\section{CONCLUSIONS}

In conclusion, shortening the dry period to $35 \mathrm{~d}$ resulted in a significant depression of subsequent milk yield in primiparous cows, but no effect on multiparous cows. Providing a 35-d dry period to multiparous Holstein cows did not affect subsequent lactation milk production; these cows produced an additional $285 \mathrm{~kg}$ of milk in the extended lactation. Milk protein yield in primiparous cows was reduced when the dry period was shortened to $35 \mathrm{~d}$. Finally, assigning overconditioned, multiparous cows to a 35-d dry period would be an appropriate management strategy.

\section{ACKNOWLEDGMENTS}

The authors would like to thank the farm personnel of Shir-o-Goosht (Esfahan, Iran) who allowed us to conduct this experiment in the complex. Additionally, the authors would like to thank Yadollah Moharrami and Shahriar Kargar (Isfahan University of Technology, Iran) for their help and assistance in conducting this experiment.

\section{REFERENCES}

Accorsi, P. A., B. Pacioni, C. Pezzi, M. Forni, D. J. Flint, and E. Seren. 2002. Role of prolactin, growth hormone and insulin-like growth factor 1 in mammary gland involution in the dairy cow. J. Dairy Sci. 85:507-513.

Annen, E. L., R. J. Collier, M. A. McGuire, J. L. Vicini, J. M. Ballam, and M. J. Lormore. 2004. Effect of modified dry period lengths and bovine somatotropin on yield and composition of milk from dairy cows. J. Dairy Sci. 87:3746-3761.

Annen, E. L., A. C. Fitzgerald, P. C. Gentry, M. A. McGuire, A. V. Capuco, L. H. Baumgard, and R. J. Collier. 2007. Effect of continuous milking and bST supplementation on mammary epithelial cell turnover. J. Dairy Sci. 90:165-183.
Bachman, K. C. 2002. Milk production of dairy cows treated with estrogen at the onset of a short dry period. J. Dairy Sci. 85:797-803

Bachman, K. C., and M. L. Schairer. 2003. Invited review: Bovine studies on optimal lengths of dry periods. J. Dairy Sci. 86:3027-3037.

Cameron, R. E., P. B. Dyke, T. H. Herdt, J. B. Kaneene, R. Miller, H. F. Buckholz, J. S. Liesman, M. J. Vandehaar, and R. S. Emery. 1998. Dry cow diet, management, and energy balance as risk factors for displaced abomasum in high producing dairy herds. J. Dairy Sci. 81:132-139.

Capuco, A. V., S. E. Ellis, S. A. Hale, E. Long, R. A. Erdman, X. Zhao, and M. J. Paape. 2003. Lactation persistency: Insights from mammary cell proliferation studies. J. Anim. Sci. 81(Suppl. 3): $18-31$.

Chilliard, Y. 1999. Metabolic adaptations and nutrient partitioning in the lactating animal. Pages 530-552 in Biology of Lactation. J. Martinet, L. M. Houdebine, and H. H. Head, ed. Institut National de la Recherche Agronomique (INRA), Paris, France.

Coppock, C. E., R. W. Everett, R. P. Natzke, and H. R. Ainslie. 1974. Effect of dry period length on Holstein milk production and selected disorders at parturition. J. Dairy Sci. 57:712-718.

Custer, E. M., J. L. Myers, P. L. Poffenbarger, and I. Schoen. 1983. The storage stability of $\beta$-hydroxybutyrate in serum, plasma, and whole blood. Am. J. Clin. Pathol. 80:375-380.

Emery, R. S., J. S. Liesman, and T. H. Herdt. 1992. Metabolism of long chain fatty acids by ruminant liver. J. Nutr. 122:832-837.

Farries, E., and S. Hoheisel. 1989. The influence of reduced dry period on some performance and metabolism traits in dairy cows. J. Dairy Sci. 72(Suppl. 1):565. (Abstr.)

Grummer, R. R. 1993. Etiology of lipid-related metabolic disorders in periparturient dairy cows. J. Dairy Sci. 76:3882-3896.

Grummer, R. R., and R. R. Rastani. 2004. Why re-evaluate dry period length. J. Dairy Sci. 87(E Suppl.):E77-E85.

Gulay, M. S., M. J. Hayen, K. C. Bachman, T. Belloso, M. Liboniand, and H. H. Head. 2003. Milk production and feed intake of Holstein cows given short (30-d) or normal (60-d) dry periods. J. Dairy Sci. 86:2030-2038.

Gulay, M. S., M. J. Hayen, H. H. Head, C. J. Wilcox, and K. C. Bachman. 2005. Milk production from Holstein half udders after concurrent thirty- and seventy-day dry periods. J. Dairy Sci. 88:3953-3962.

Gumen, A., R. R. Rastani, R. R. Grummer, and M. C. Wiltbank. 2005. Reduced dry periods and varying prepartum diets alter postpartum ovulation and reproductive measures. J. Dairy Sci. 88:2401-2411.

Hales, C. N., and P. J. Randle. 1963. Immunoassay of insulin with insulin antibody precipitate. J. Biochem. (Tokyo) 88:137-146.

Herdt, T. H. 1992. Therapy of diseases of ruminant intermediary metabolism. Vet. Clin. North Am. Food Anim. Pract. 8:91-106.

Hurley, W. L. 1989. Mammary function during involution. J. Dairy Sci. 72:1637-1646.

Kuhn, M. T., and J. L. Hutchison. 2005. Methodology for the estimation of days dry effects. J. Dairy Sci. 88:1499-1508.

Li, P., P. S. Rudland, D. G. Fernig, L. M. B. Finch, and C. J. Wilde. 1999. Modulation of mammary development and programmed cell death by frequency of milk removal in lactating goats. J. Physiol. 519:885-900.

Lotan, E., and J. H. Adler. 1976. Observations on the effect of shortening the dry period on milk yield, body weight, and circulating glucose and FFA levels in dairy cows. Tijdschr. Diergeneesk. 101:77-82.

Lowman, B. G., N. Scott, and S. Somerville. 1976. Condition Scoring of Cattle. Rev. ed. Bull. East of Scotland College of Agriculture, No. 6. East of Scotland Coll. Agric., Edinburgh, Scotland.

Makuza, S. M., and B. T. McDaniel. 1996. Effects of days dry, previous days open, and current days open on milk yields of cows in Zimbabwe and North Carolina. J. Dairy Sci. 79:702-709.

Morton, J. 2004. Determinants of reproductive performance of dairy cows in commercial herds in Australia. PhD thesis. Univ. Melbourne, Australia. 
National Research Council. 2001. Nutrient Requirements of Dairy Cattle. Natl. Acad. Press, Washington, DC.

Natzke, R. P., R. W. Everett, and D. R. Bray. 1975. Effect of drying off practices on mastitis infection. J. Dairy Sci. 58:1828-1835.

Pandey, R. S., D. S. Bhatnagar, and M. Gurnani. 1978. Inheritance of dry period and its effect on subsequent lactation yield in Tharparkar cattle. Indian Vet. J. 55:935-939.

Rajala-Schultz, P. J., J. S. Hogan, and K. L. Smith. 2005. Short communication: association between milk yield at dry-off and probability of intramammary infections at calving. J. Dairy Sci. 88:577-579.

Rastani, R. R., R. R. Grummer, S. J. Bertics, A. Gumen, M. C. Wiltbank, D. G. Mashek, and M. C. Schwab. 2005. Reducing dry period length to simplify feeding transition cows: Milk production, energy balance, and metabolic profiles. J. Dairy Sci. 88:10041014.

SAS Institute. 1999. SAS User's Guide. Statistics. Version 8.2 ed. SAS Institute Inc., Cary, NC.

Schairer, M. L. 2001. Estrogen treatments for the initiation of dryoff in dairy cows. MS thesis. Univ. Florida, Gainesville.
Smith, A., J. V. Wheelock, and F. H. Dodd. 1967. The effect of milking throughout pregnancy on milk secretion in the succeeding lactation. J. Dairy Res. 34:145-150.

Smith, J., and K. Becker. 1995. 50 to 59 days dry has highest production. Hoard's Dairyman 140:6.

Smith, J. W., and J. E. Legates. 1962. Relation of days open and days dry to lactation milk and fat yields. J. Dairy Sci. 45:1192-1198.

Sørensen, J. T., and C. Enevoldsen. 1991. Effect of dry period length on milk production in subsequent lactation. J. Dairy Sci. 74:1277-1283.

Swanson, E. W. 1965. Comparing continuous milking with sixty-day dry periods in successive lactations. J. Dairy Sci. 48:1205-1209.

Trinder, P. 1969. Determination of glucose in blood using glucose oxidase with an alternative oxygen acceptor. Ann. Clin. Biochem. $6: 24-27$.

Wheelock, J. V., J. A. F. Rook, and F. H. Dodd. 1965. The effect of milking throughout the whole of pregnancy on the composition of cow's milk. J. Dairy Res. 32:249-254.

Wilton, J. W., E. B. Burnside, and J. C. Rennie. 1967. The effects of dry days and days open on the milk and butterfat production of Holstein-Friesian cattle. Can. J. Anim. Sci. 47:85-90. 